which is fully described in the communications already alluded to. By this means the positions of the various inequalities around twenty-four days have been indicated on the time-scale. I have next taken two of these and attempted to eliminate from them the influcnce of all neighbouring inequalities, in order to sce with what success it is possible to disentangle the various periods from each other. In order to test this success I have exhibited in the tables on p. 81 the result of this elimination applied to each four years of sun-spot records, and I think it will be manifest to every one that there is such evidencc of repetition, that one cannot doubt the reality of the periods therein indicated. I have likewise begun to apply to these records Gen. Strachey's test, and with a good result so far as I have yet gone.

No kind of smoothing or equalisation has been applied, and the elimination has been carried on only to the first stage, so that more accurate determinations will probably result from a further application of labour.

\section{BALFOUR STEWART}

\section{PRIMITIVE $M A N^{1}$}

$\mathrm{I}^{\mathrm{T}}$ $T$ is a familiar fact that from time to time wrong-headed but enthusiastic persons appear in the scientific arena boldly challenging the truth of some one or other of the most firmly-established and essential doctrines of the scientific creed. Sometimes a clever investigator discovers that we moderns are all in the wrong, and that the sun after all goes round the earth; another will have it that the moon does not revolve on its axis; a third disputes the correctness of the theory of gravitation; whilst a fourth finds no difficulty whatever in squaring the circle. Such men have cropped up at intervals throughout the historical period. 'They are not without their usefulness in their generation, for they afford some little mirth, and give an opportunity sometimes to men of science to reconsider their standpoints and settle themsclves more firmly upon them. It seems uncertain whether Prof. Dawson, of McGill College, Montreal, is to bc classed with these malcontents, or whether his scientific heresies are to be explained as conforming to the general law that superstitions generally survive and even thrive in colonies long after they have dicd out in their mother country.

No greater contrast could well be conceived than is presented by the two works on Primitive Man which have just appeared, and which form the subject of the present article.

Prof. Boyd Dawkins, in accordance with the teachings set forth in his "Cave Hunting" and all other works which have procceded from bis pen, treats his subject in a thoroughly scientific and unprejudiced manner, and the results which he lays before his readers are in keeping with the conclusions now fully accepted by all anthropologists and admitted by cducated persons generally. Prof. Dawson, on the other hand, has actually written a book at this present time, the object of which is to attempt to show that mankind first made its appearance on the earth not more than 6,000 or 8 ,oco years ago. He sums up thus :"What evidence the future may bring forth I do not know, but that available at present points to the appearance of man with all his powers and properties in the Post-glacial age of geology, and not more than 6,000 to 8,000 years ago." His book is described as "an attempt to illustrate the characters and condition of prehistoric men in Europe by those of the American races." His arguments are old stagers long ago upset. Such, for example, as that because some savages, such as the Veddahs of Ceylon, who are degraded Singhalese, are degencrate, therefore

" "Early Man in Britain and His Place in the Tcrtiary Pericd." By W. Boyd Dawkins, M.A., F.R.S., \&c. (Lendcn: Macmillan and Co., r88o.) LL.D., F.R.S., \&c., McGill College, Mlontreal. (Ly Stoughton, 1880.) all savages are the degenerate offspring of highly-cultivated races. On similar grounds we might infer that because barnacles and ascidians can be shown to be degenerate animals, therefore all lower animals have undergone "degeneration," to use Prof. Ray Lankester's term, and all monkeys are degenerate men.

The main argument of the book is however apparently that derived from the results of excavations made on the site of Montreal. On this site, as we know from Cartier's narrative, stood in 1535 the native town of Hochelaga, which was fortified, as shown in the plan of the town at the end of the third volume of Ramusio's collection of Voyages and Travcls, by means of a circular triple wall of wooden beams, the outcr of which were inclined to meet one another at the summit. The native town, its buts and walls, naturally disappeared within a century, and all that now remains of it are the implements and bones which are to be dug out on its site, and of which Prof. Dawson gives an interesting account. There are tobacco pipes of various kinds, stone weapons, pottery, and bones of animals and men. If it had not been for Cartier's visit and published narrative antiquarians might have ascribed a very early date to these remains, argues the author, therefore in all cases where a very early date has been assigned to human remains of the palæolithic age in Europe a similar error has been committed. We cannot follow Prof. Dawson through his attempts to contort the data of modern science into accordance with Chaldxan cosmogonies and mythology as familiar to us in Jewish dress. He gravely refers the remains found at the camping ground at Solutre which, according to $M$. de Mortillet, mark a special epoch (the Solutrian) in the palæolithic age, to the antedilurian epoch, and reminds us how Jabal, before the flood, according to Genesis, initiated the nomadic mode of life, suggesting that the old inhabitants of Solutre who hunted the mammoth, the cave lion and cave bear, were Jabalites. It is delightful to find how beautifully everything fits into its place when freely interpreted by Prof. Dawson. The results of his ethnographical and antiquarian researches appear to be more or less summed up in the biblical text, "God shall enlarge Japhet, and he shall dwell in the tents of Shem, and Canaan shall be his servant." This means, as he aptly explains, that the Aryan or Japetic races were to be endowed with "the higher control of the physical forces and the greater power of expansion and propagandism," in short, amongst other exploits, to exterminate the Redskins and colonise America; whilst the Semitic races were to receive historical and spiritual revelations, and Canaan in the text represents unprogressive humanity generally.

Prof. Dawson's intimate acquaintance with the details of prehistoric religion is most startling. He holds up the faith of palacolithic, or palaocosmic, man, as be prefers to call him, as a warning and a pattern to the degraded Ritualist, at whom he cannot help having a dig even with palæolithic weapons, being evidently a staunch l'rotestant. He slays evolutionists with the same thrust. It is an unexpected honour for them to die in such company. No coubt the association is meant to give the Ritualists the hardest dig. He wishes "distinctly to affirm that the prehistoric religions, and what we call heathenism or aninism of untaught tribes, were nearer to God and truth than are either the ritualisms and idolatrics or the materialistic scepticisms of more civilised times, when men, 'professing themselves to be wise, become fools.' " Till we read this passage it seemed to us that Prof. Dawson professed himself throughout his book to be very wise incleed, but of course he cannot have intended to pose in that attitude. The chapter concludes by calling on "all men cverywhere to repent," and so we do heartily of having followed so far Prof. Dawson's, shall we call it "wisdom"?

We turn with relief to Prof. Boyd Dawkins's finc volume. It is sumptuously printed, and contains 168 
excellent illustrations, the sources of which are given in and the successive faunas and fioras of preceding geoa table at the commencement of the work, a detail of importance often onitted.

The first chapter deals with the relation of geology to archæology and history, these tbrec sciences all contributing to the building up of the account of carly man in Britain. There appears to be a slip in the table showing the specialisation of mammalia in the tertiary period, logical periods in Britain, the account of the miocene age is concluded with a paragraph headed "No l'roof of Man in Europe in the Miocene Age." High authorities such as Dr. Hamy and M. de Mortillet have maintained that man dicl exist in France as early as the middle of the miocene age, basing their conclusions on the evidence given by splinters of flint found in mid-miocene strata at

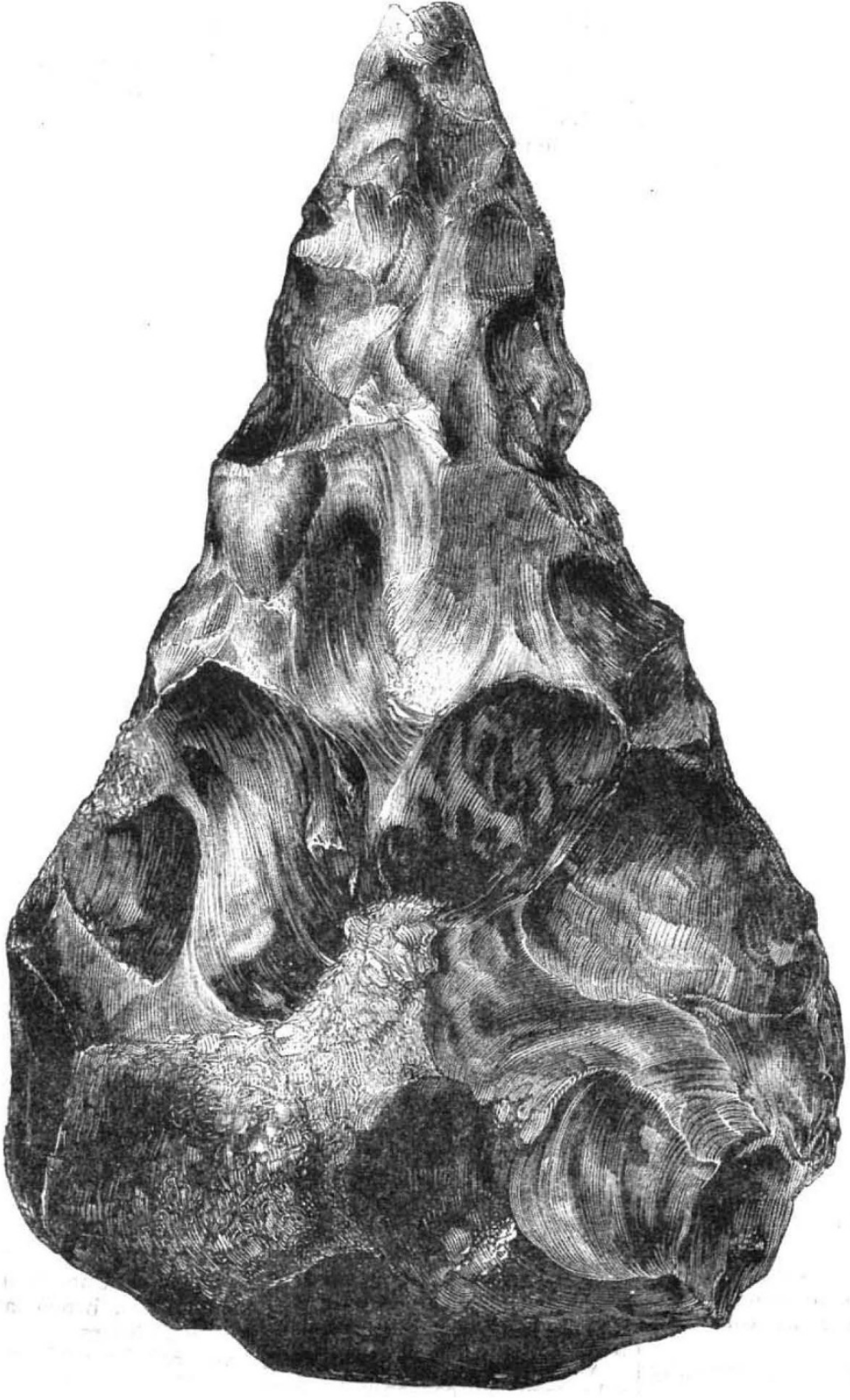

FIG. . - Flint River Drift_Implement,_Gray's Inn Lane, t. Thenay by the Abbe Bourgeois, and by a notched fragment of a rib found at Pouance by M. Delauny. The author seems a little in doubt whether these flakes and notches are in reality artificial, but if they be so he prefers to conclude, with Prof. Gaudry, that they were made by the anthropomorphous apes then inbabiting France rather than by man. This appears to be a somewhat wild suggestion, and the author is evidently led to it by considerations which are sct forth in the same paragraph, and which seem to him to prove that from zoological grounds man could not have existed in the miocene age, as to the cogency of which considerations we cannot at all agrce with him. His argument is that because no other living species of land mammal has been met with in the miocene fauna, therefore man could not have formed an exception to this supposed rule, and "had no place in a fauna which is conspicuous by the absence of all the manmalia now associated with him." "If miocene man had existed it is incredible that he alone of all the mammalia living in these times in Europe should not bave perished or have changed into some other form in the lapse of ages." The author adds: "Those who believe in the doctrine of evolution will see the full force of this argument against the presence of man in the miocene fauna not merely of Europe but of the whole world." Now we, we hope in common with all the readers of NATURE, are thorough-paced evolutionists, but we should have said rather that those who understand the doctrine of evolution would consider this argument as completely unsound. Evolution, wherever variedly manifested in its action, does not produce any comprehensive similar effect on any group of different objects on which it acts. According to the varying conditions partly surrounding, partly embodied in each object, evolution singles out certain of the objects for higher specialisation, others for degradation, others again for extinction; whilst others again it as it were, leaves alone to survive unchanged through ages amongst hosts of modified descendants of their near relatives. The survival of some form, larval or adult,

where the period is divided into the eocene, miocene, pleiocene, pleistocene, prehistoric, and historic stages. The latter stage is said to be characterised by living species of mammalia and no extinct specics, which is rather misleading, since Steller's sea-cow is almost certainly extinct, and several other mammalia are verging on extinction.

After an interesting sketch of the physical conditions or of some organ of great antiquity in unchanged condition, where all the concomitants have become profoundly modified, is one of the most familiar facts explained by the evolution theory. How is it else that the brachiopod Lingula has survived in nearly identical form to the present day from the earliest geological times, whilst all its then contemporaries are extinct or have changed? How is it else that the vertebrate structure survives in 
only one or two of the degenerate Ascidians? How is it else that some savages are still in their stone age, and that Prof. Dawson still believes that mankind is only $6, \infty 00$ years old?

We see no reason whatever, from evolutionary grounds, why man should not have existed in the miocene times. Anthropomorphic apes were already in those times abundant and varied, and comparative anatomy points to the progenitor of man having been an ancestor of the present existing anthropomorphs, combining many of their several characters. At the same time we do not wish to appear to assert that man did then exist, but we think it rather a pity that the author did not give good illustrations of the miocene flint flakes and the notched rib if only to show, as we believe is the case, that they do not exhibit any very definite traces of handiwork, and has not formed a more certain judgment as to whether the objects are artificial or not.

We have dwelt upon this matter at some length, because an important question of principle is involved in which we are at variance with the author. With regard to everything else in the book we cannot but offer our best thanks to him. His extended experience in cave-hunting, his critical knowledge of geology and of the later tertiary mammalia, have long rendered him an authority of first rank on the subject of which he treats, and he has in the present volume combined with great care all available published information with the results of his own investigations. The book represents with great clearness the present state of our knowledge with regard to the antiquity of

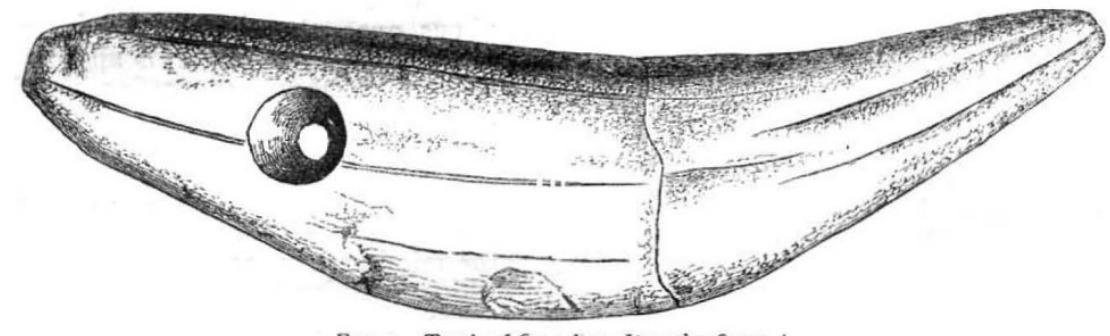

Fig 2,-Tost' of Cave hoon, Uuruthy Cave. 1.

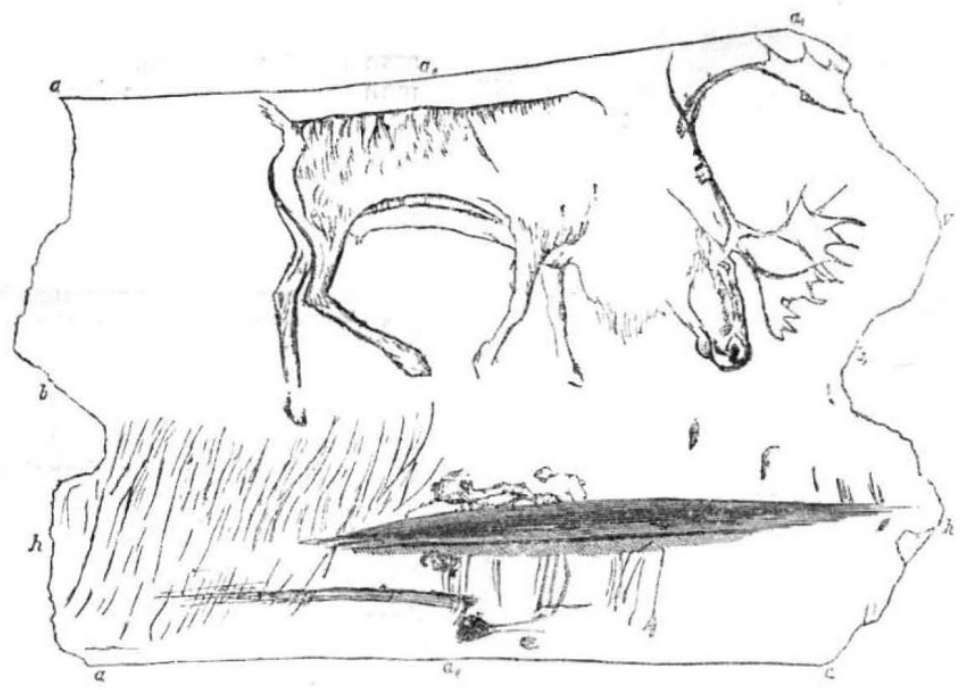

FrG. 3.-Reindeer incised on antler, Kesserloch, $\mathbf{3}$.

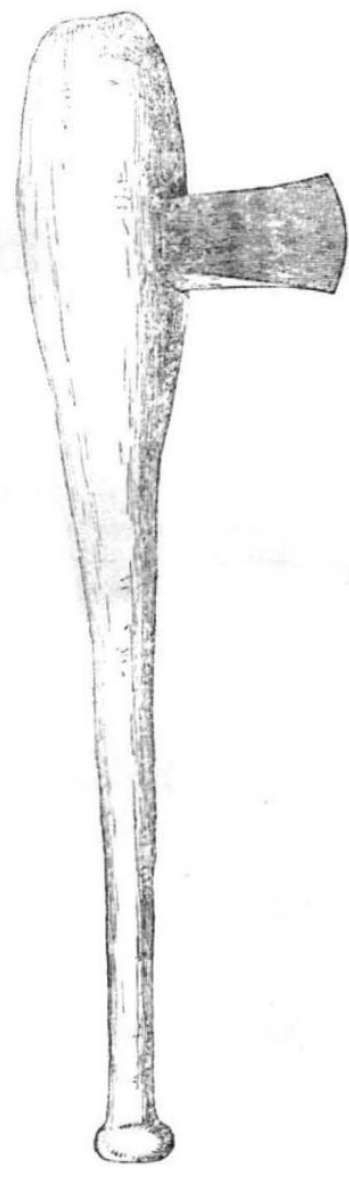

Fig. 4,-Stone hatchet, Robenhausen, man, for though it treats principally of Early Man in Britain, no details of importance with regard to discoveries bearing on the subject on the Continent or elsewhere are omitted.

The whole account is most clearly and logically arranged, and written in a very readable and entertaining style. It is popular as well as scientific.

The author considers the evidence of man in early pleistocene strata as doubtful. It is in the mid-pleistocene deposits that man first appears without any doubt, as proved by flint implements found in the lower brick-earths at Crayford by the author himself. Man was at that period associated in the Thames valley with six extinct species of mammalia, viz., three species of rhinoceros, $R$. megarhinus, tichorhinus, and leptorhinus, the mammoth and Elephas antiquus, and the Irish elk. Large herds of horses, stags, and bisons frequented the open country, the hippopotamus floated about lazily in the Thames, whilst the thickets were inhabited by wolves, foxes, brown and grisly bears, huge lions, hyænas, and wild boars.

We cannot here follow the author throughoit his welltold story, but can only dip here and there into his work to give our readers a sample of its qualities. Most interesting is a palæolithic implement discovered in England so long ago as the year 1690 . It was found with the remains of an elephant in the heart of London in the gravel at Gray's Inn Lane, and having been preserved in the Sloane collection in the British Museum for more than 150 years, was ultimately recognised by Mr. A. W. Franks as identical with those discovered so long afterwards in the gravels of Amiens an 1 Abbeville. It belongs to the late pleistocene river deposits. The accompanying 
figure of it is taken from Mr. John Evans's "Ancient Stone implements."

The author carefully considers, as far as the evidence will permit, the question of the range of the Cave men as compared with the River-drift men. The remains of the "Cave men," who are characterised by the use of certain peculiar implements, are found throughout the whole of France, and are remarkably abundant in the caverns of the Pyrenees. They occur also in Switzerland, Germany, Belgium, and England, but are limited in range, being unknown as yet in the caves south of the Alps and Pyrenees, and north of a line passing east and west from Derbyshire through Belgium. The Cave men differed in race from the River-drift men. They were ignorant of pottery, but they had a varied assortment of implements and weapons of bone, ivory, and stone. They prized ornaments, and in the cave at Duruthy forty canine teeth of the bear and the lion were found perforated to form a necklace, "a magnificent trophy of the chase."

The Cave men were also artists, and engraved drawings of very considerable artistic merit on bones, ivory, and antlers. Their drawings of the mammoth on its own ivory are familiarly known. We reproduce here a figure of a reindeer incised on an antler from the Kesserloch, near Thaynigen.

Drawings of the great Irish elk, bisons, the ibex, and bears have also been discovered, but those of man are extremely rare, and comparatively badly executed. Mr. John Evans is inclined to hold that the Riverdrift and Cave men belonged to the same age and the same race, but the author concludes that they must be referred either to two distinct races or to two sections of the same race which found their way into Europe at widely different times ; the River-drift men being of far higher antiquity in Europe, and probably having lived for countless generations before the arrival of the Cave men and the appearance of higher culture. "The discoveries of the last twenty years bave tended to confirm the identification of the Cave men with the Eskimos.'

The account of the Cave men is followed by that of the prehistoric period, of the neolithic civilisation, the age of polished stone implements and of the prehistoric farmer and herdsman. Wild boars, the great wild ox, the urus, the Irish elk, the reindeer, the brown and grizzly bear still inhabited Britain during that period. The Irish elk is remarkable for being the sole survivor amongst land mammalia from the pleistocene to the prehistoric age which has since become extinct. Its rarity in Britain forms a marked contrast with its abundance in Ireland. It has been found in England, near Newbury in Berkshire, and at Maybole in Ayrshire. In the neolithic period the dog, horse, sheep, goat, shorthorn, and hog were already domesticated.

"Of all the neolithic implements the axe was by far

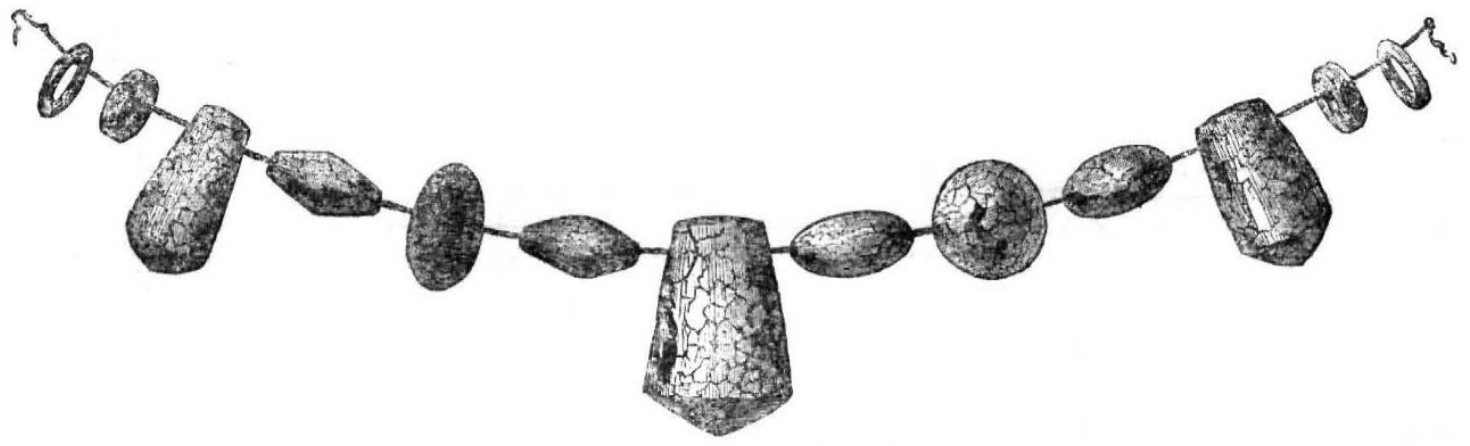

Fig. 5.-Amber necklace Laka, Wilts,

the most important. It was by the axe that man achieved his greatest victory over nature, by clearing the land of forest. It was immeasurably superior to the rude flint häche of the palæolithis hunter, which could not make a straight cut in wood, and which was very generally intended for use in the hand, without a handle. It is therefore chosen as the symbol of the neolithic culture."

In New Guinea and its neighbourhood land is still cleared of forest by the natives for culture by the aid of fire and the stone hatchet.

Chapter X. treats of the further development of culture, the Bronze age, and the invasion of the British Isles by the Celts, who are proved by their tombs, scattered over the face of the country, alike in England, Scotland, Wales, and Ireland, to have conquered nearly every part of the British Isles. In the Bronze age the number and variety of the weapons, implements, and ornaments belonging to the men of the period become greatly increased, and their culture presents a far more complicated problem for study than that of their simpler predecessors. Mr. John Evans, who, as the highest authority on early bronzes, is followed by the author, divides the Bronze age into two periods-the Early and the Late ; the first of these was a period of transition, when the use of bronze was superseding that of stone, and is characterised by the presence of bronze daggers and plain wedge-shaped axes, originally modelled from stone prototypes. The later division of the Bronze age is characterised by the appearance of swords, spears, palstaves, and socketed celts. Already in the early Bronze age such articles of advanced development as tweezers and combs of bone, amber and glass beads, jet buttons, and bronze finger-rings and ear-rings were in use. The accompanying woodcut represents an amber necklace of the Bronze period found at Lake, in Wiltshire. Even gold is found amongst the remains of this age.

We cannot follow the author in his account of the temples of the Bronze age, Avebury and Stonehenge, nor

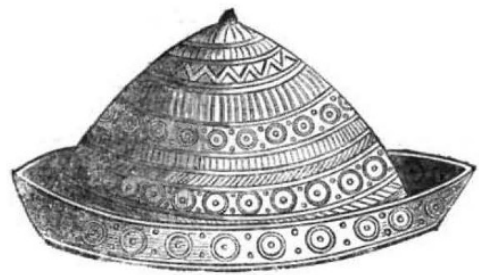

FIG. 6.-Golden cap. Devil's Bit, Tipperary.

in his description of the methods by which the bronze was worked, of the artistic designs of the period, and of the curious hoards of bronze merchandise which have been found in France, and the pick of which has, we believe, found its way into Mr. John Evans' hoard. 'The twelfth chapter deals with the prehistoric iron age north of the Alps, the arms and equipage, personal ornaments, late Celtic art, Etruszan influence on art, \&c. Arts in 
this period reached a very advanced development indeed, as may be seen from the appended figure of a golden cap found in Tipperary. It is most beautifully ornamented in repoussé.

Silver and gold ornaments in this age became abundant. The concluding chapters in the book are on the Overlap of History (the Egyptian, Assyrian, Phœnician, and Greek Influences) and on Britain in the Historic Period (the Exploration of the British Coasts, and Roman Britain). We cannot follow the author further, but commend his book to our readers as one that will well repay perusal throughout.

\section{THE HYDROGRAPHIC DEPARTMENT}

W

$\mathrm{E}$ observe that some of our contemporaries have opened their columns to certain strictures upon a public department standing well, and to our knowledge deservedly so, in the estimation of scientific circles in this and other countries.

It would appear that a Lieutenant of the Royal Navy, unknown, as we are informed, in his profession from the fact of his having retired from its active service at an early age, amused himself some few years back by a yachting excursion on the shores of Norway, in a small and crazy decked boat, undergoing, as might have been anticipated, some hardships in this excursion, which extended into the rigorous winter of that region. Gaining thus some knowledge of the coast traversed-but necessarily, from its great extent and intricate character, knowledge of a very superficial kind-the Lieutenant's experiences have recently formed the subject of an evening's entertainment at the Royal Geographical Society. Somewhat unfortunately for the ends of science and navigation, this adventurous cruise in a crazy barque has been in consequence dignified into a hydrographical survey, an appellation ludicrously inapplicable from the conditions under which the cruise was made, as related by the adventurer himself.

The ambitious voyageur, now extending his operations, under the leadership of an official of the Royal Geographical Society, has just addressed an audience at the Society of Arts on the " Trade Routes between England, Norway, and Siberia." We had expected at least some shreds of information on this topic, but find ourselves treated instead to a rucle and ungenerous attack on the Hydrographic Department of the Admiralty, for some supposed shortcomings in its dealings with the officer, to whom the department had confided-mistakenly it seems-the revision of the sailing directions of that part of Norway on which the Lieutenant claimed to be an authority.

The Society of Arts commends itself to all reasonable men for the breadth and strength of its operations ; we regret that it should in this instance have been exploitéd and made the arena, under cover of a legitimate object, for an attack, from personal motives, on a public department which has done and is doing good and honest service for the seamen of all nations. We believe we are only performing an act of merited justice in directing attention to the endeavours of a small, obscure, but selfasserting clique, bent apparently on discrediting a valuable and efficient department, affiliated in many. ways to science, and well known to many of its ablest workers.

\section{NOTES}

PRor. W. H. Miller died at Cambridge on Thursday, May 20 , in his eightieth year. He graduated in 1826 , being Fifth Wrangler, and shortly afterwards became a Fellow of St. John's College. He served his college as tutor during several years. On the resignation of Dr. Whewell in 1832 he became Professor of Mineralogy. He published his celebrated "Treatise on Crystallography" in 1838 . This work was at once adopted by some of the most eminent foreign crystallographers, and may now be said to be universally accepted. It was translated into German and French. His "Manual of Mineralogy" appeared in 1854, and, like the former book, forms an era in the history of the science. It is full of the results of his own careful research. He is the author of several other books, and of numerous memoirs published in the various scientific journals. The memoir on the standards of weights is a classical research on the subject of weights, and is a monument of delicate and careful research. He was Foreign Secretary of the Royal Society, and was presented with the Society's gold medal in 1870 for his numerous contributions to science. Cambridge has especial cause to be grateful to him for the very splendid collection be has brought together. The collection consists almost entirely of donations; and the two noble gifts of the Hume and Brooke collections mark in a striking manner the appreciation in which Prof. Miller was held by lovers of minerals.

ON the same day as Prof. Miller died Prof. David Thomas Ansted, F.R.S., at the age of sixty-six years. Prof. Ansted was born in London in the year 1814. He graduated at Jesus College, Cambridge, was a Wrangler in 1836, and was elected in due course a Fellow of his college. In 1840 he was appointed to the Professorship of Geology in King's College, London. Five years later he became lecturer on geology at Addiscombe College, and also at the Civil Engineering College at Putney. About the same time he was made assistant secre. tary to the Geological Society, whose quarterly journal he edited for many years. From about $185^{\circ}$ down to a very recent date he was extensively engaged in the application of geology to the engineer's work, in mining, and in various other departments of industry. $\mathrm{He}$ has also been frequently employed as an examiner in physical geography under the officers of the Government Department of Science and Art. Prof. Ansted's works are very numerous; among them may be mentioned-besides his contributions to the transactions of learned and scientific societies-his "Application of Geology to the Arts and Manufactures," his "Physical Geography," his "Elementary Course of Geology and Mineralogy," and "The World we live in." Prof. Ansted was elected a Fellow of the Royal Society in 1844 .

General Myer has sent a letter to his numerous correspondents, requesting, on behalf of the United States, that the hour for taking the simultaneous meteorological observations, from which are constructed the U.S. Weather Maps, be changed to a time thirty-five minutes earlier than at present; in other words, as regards the British islands, that the observations be made at oh. $8 \mathrm{~m}$. p.m., instead of oh. $43 \mathrm{~m}$. p.m. Greenwich mean time, and that the change be made to take effect on September $\mathbf{r}$, 1880. The proposed change being rendered necessary by the exigencies of the Signal Office, the request will doubtless be gladly acceded to.

THE second example of Archacopteryx is, we are informed, at present merely on deposit in the Geological Museum of Berlin, under the care of Dr. Beyrich, although it is expected that arrangements will shortly be made for its purchase by the authorities of that institution. It was bought from Dr. Haeberlein, of Pappenheim, by Herr Siemens, of Berlin, for the sum of 20,000 marks $\left(I, \mathrm{CoO}_{2}\right.$ ), in order to save it from an impending transfer to America, and to secure this valuable specimen for German science.

TнF. "Leopoldinische-Carolinische" Academy of Naturalists at Halle has presented this year's Cothenius medal to Dr. A. Michaelis, Professor of Chemistry at the Polytechnic High School of Karlsruhe, in recognition of his valuable researches in organic substances containing phosphorus. 